\title{
The Descriptive Analysis of Students' Writing Ability in Narrative Text at the Eighth Grade of SMP Negeri 1 Gunungsitoli Barat in 2020/2021
}

\author{
Analisis Deskriptif Kemampuan Menulis Teks Narasi Siswa Kelas VIII SMP Negeri 1 \\ Gunungsitoli Barat Tahun 2020/2021
}

\author{
Hasrat Sozanolo Harefa \\ IKIP Gunungsitoli \\ Jalan Yossudarso No. 118 E/S Gunungsitoli \\ sozanoloe@gmail.com
}

\author{
Joshua Obedience Zebua \\ IKIP Gunungsitoli \\ Jalan Yossudarso No. 118 E/S Gunungsitoli \\ joshuaobediencezebua@gmail.com
}

\begin{abstract}
Writing is one of the four language skills that should be mastered by students. The syllabus of SMP Negeri 1 Gunungsitoli Barat expects the students to be able to compiling the narrative text in the form of personal experience. The purpose of the research was describing the students' writing ability in narrative text and the factors affecting it. The method used in the research was descriptive qualitative. The analysis of the data was conducted by following steps. Analyzing the quantitative data by using analytic scoring rubric from Glenceo namely, focus/organization, elaboration/support/style, and grammar and mechanics and analyzing the qualitative data through transcripts of structure interviews. Furthermore, the informant of the research was class VIII-A students of SMP Negeri 1 Gunungsitoli Barat which consisted of 20 students. The data were collected through documentary data of students' worksheets and interview both students and English teacher. The result showed that the students' ability in writing narrative text was in Good category (66 score). It is proved by the findings that there were 7 students (35\%) included in 'Excellent' category, there were 4 students (20\%) included 'Good category, there were 3 students (15\%) included 'Fairy' category and category included in 'Poor' were 6 students (30\%). Furthermore, the factors that affect the students' ability in writing narrative text were: students cognitive it was problem organization, less motivation, lack of grammar, lack of practice and the influence of the first language (L1) on writing in English.
\end{abstract}

Keywords: writing skill, narrative text

Abstrak

Menulis merupakan salah satu dari empat keterampilan berbahasa yang harus dikuasai oleh siswa. Silabus SMP Negeri 1 Gunungsitoli Barat mengharapkan siswa mampu menyusun teks naratif dalam bentuk pengalaman pribadi. Tujuan dari penelitian ini adalah mendeskripsikan kemampuan menulis siswa dalam teks naratif dan faktorfaktor yang mempengaruhinya. Metode yang digunakan dalam penelitian ini adalah deskriptif kualitatif. Analisis data dilakukan dengan langkah-langkah berikut. Menganalisis data kuantitatif dengan menggunakan rubrik penilaian analitik dari Glenceo yaitu focus/organization, elaboration/support/style, dan grammar and mechanics serta menganalisis data kualitatif melalui transkrip wawancara struktur. Selanjutnya informan penelitian ini adalah siswa kelas VIII-A SMP Negeri 1 Gunungsitoli Barat yang berjumlah 20 siswa. Pengumpulan data dilakukan melalui data dokumen lembar kerja siswa dan wawancara siswa dan guru bahasa Inggris. Hasil 
penelitian menunjukkan bahwa kemampuan siswa dalam menulis teks naratif berada pada kategori Baik (skor 66). Hal ini dibuktikan dengan temuan bahwa terdapat 7 siswa (35\%) termasuk dalam kategori 'Sangat Baik', ada 4 siswa (20\%) termasuk kategori 'Baik', ada 3 siswa (15\%) termasuk kategori dan kategori 'Cukup'. termasuk dalam 'Buruk' sebanyak 6 siswa (30\%). Faktor-faktor yang mempengaruhi kemampuan siswa dalam menulis teks naratif adalah: kognitif siswa itu adalah organisasi masalah, kurang motivasi, kurangnya tata bahasa, kurangnya latihan dan pengaruh bahasa pertama (L1) dalam menulis dalam bahasa Inggris.

Kata kunci: keterampilan menulis, teks narasi

\section{INTRODUCTION}

The skill of Writing in the students' second language can be something difficult for students, whereas the students often write in their first language in schools. Therefore, in most the processes of learning and also teaching English language, writing skill is sometimes considered as the most complicated and difficult skill for the students of any level of education. It is supported by Langan (2011) in Umar (2016:21) states, writing is actually a skill which grows as a result of constant practices. One of the writing that close to the learners' subject is narrative text. Anderson (1997, p. 8) in Hariyadi (2018:65) points out that a text that tells a story is called a narrative, and, because of that, audience will be entertained by that. Based on this, it can be concluded that a story which use written or spoken language can be called narrative text.

Writing comes at the end of one's mastery over the other three skills. writing is a useful tool for discovering, thinking and delivering meaning. Hourani (2008) in Murdliayan (2019: 200) says that, writing skills must be experienced and practiced. Furthermore, Oshima and Ann (2007) in Autilia and Theresia (2018: 149) justify that if the writer have some points to be told to the readers, he or she as an individual could use an act called writing, which have some steps such as idea thinking, transferring the idea onto the words and then reassess the words until those set of words could express the exact ideas.

There are 6 steps such as prewriting, outlining, drafting, revising, editing and publishing if a person wants to do a writing process.

1. Prewriting. According to Graham (2006) in Mustika et al (2018: 207), prewriting is first step to be done as a base to the topic. In this step, the base could be extended until the organization is complete. Soon after this process, a person could arrange this idea into outline or abstract using his/her own experience to a topic

2. Outlining. In this second process, a person or a writer tend to write a key point to be the mark of his/her writing. It could be scientific or non-scientific. This is done by focusing the topic and then write down some systematic Alinea. In other words, this process can be called a "key word points".

3. Drafting. Referring to Johnson (2008, p.179) in Mustika et al (2018: 207). Drafting is the writer's aim to describes drafting as 'the writer's first attempt to apprehend his/her concepts on paper.' Specifically, this is a process where he/she as a writer determines the manuscripts or article with new objectives. The goal of drafting is to assist the reader to understand the article or paper easily. In this point also, the author could start his/her paper with introductory paragraph, body of the paragraph, and the ending. 
4. Revising. Based on Johnson (2008) in Mustika et al (2018: 207), revising is the core of the writing process since the author could improve or modify the article of the paper as long as it is needed. Additional data comes from Grave (1983) in Mustika et al (2018: 207) that said if the pupils may put an attempt to rethink and resolve which points that are suitable to improve the paper.

5. Editing. Again, in Johnson (2008) in Mustika et al (2018: 207) said that it is encouraged to the writers to always asking their assistant or proofreader to do the activity of proofreading. The proofreading must be done in order to correct the grammatical errors or mistakes in spelling. It can be done by friends or teachers.

6. Publishing. This last part means that the author can share the paper or the article with his or her readers, as said by Johnson (2008) in Mustika et al (2018: 207).

One of the texts is narrative text. a paragraph or essay that telling story or chronological the accident is Narrative text, which is the aim is to entertain and amusing the reader of this type of text. Furthermore, the reader of the text can bring out in the story and also can imagine that the story really happened in reality. Based on Asriani (2018:59) says, "a spoken or written text called Narrative text has a function to communicate a massage, which is use to interpret its meaning in the story". Furthermore, Anderson in Marzona and Ikhsan (2019:36) state that, the purpose of narrative text is to entertain the reader or listener and it can be vivid and accurate. From some theory above it can be conclude a story that made to entertain the reader is called narrative text. Furthermore, the enjoyer can felt the adventure from the personality there. Furthermore, to make the peruser fascinating with the theme, the author need to make the story with delineation. Along these lines, the peruser can felt the story like, in actuality.

Anderson in Lubis (2016:5) say that, the conventional construction of narrative text is as per the following: 1) Orientation/ Exposition. The readers are acquainted with the fundamental characters and potentially some minor characters. Some sign is by and large given of where the activity is found and when it is occurring; 2) Complication/ Rising Action. The complication is moved along by a genuine of occasions, during which we for the most part anticipate a type of inconvenience or issue to emerge. It just would not be so fascinating if something surprising didn't occur. This complication will include the primary characters and stove serves to (transiently) toward them from arriving at their objective; 3) Sequence of event/ Climax. This is the place where the storyteller advises how the person responds to the complexity. It incorporates their inclination and what they do. The occasion can be told in sequential request (the request where they occur) or with flashback. The audience is given the narrators point of view; 4) Resolution/ Falling Action. In this part, the ramifications might be settled regardless, yet it is once in a while left totally unsettled (albeit this is obviously conceivable in sure of account which leaves us; 5) Re-orientation. It is an optional closure of event.

The second study is from Noviani at all (2015) says In terms of resolution 40 students from 50 students had problems, students are not told how the problems was resolved whether to be happy or sad ending.

There are three components influencing the students' capacity in writing a narrative text based on Nile et al (2015) International Journal of English Language Teaching:

1. Cognitive Problem

a. Content Problem: Learners of English as a second or foreign language also face problem of exploring ideas and thought to communicate with others. According to Leki in Nile et al (2015) this could be a direct result of the customary techniques educators use to show composing for spelling, accentuation, and dominating sentence structure. It recommends that educators ought to urge understudies to zero in on the message, 
thoughts or contemplations they wish to pass on as opposed to language structure, spelling, accentuation and others.

b. Problem Organization: Students have the issue of organizing the section, subject advancement of passage, organizing the entire talk and a topic in a talk. Raimes states that other issue of association in student composing is the trouble of separating a point and supporting thoughts or speculations and explicit detail.

\section{Grammatical Problems}

Students have various issues in their endeavor's to write in the subsequent language. As action words take various structures relying upon tense and subject they are utilized with and they make issues for second language learning students.

\section{Lack of Practice}

Writing is basically an innovative strategy and great scholars should figure out how to impart their thoughts plainly to an inconspicuous crowd. This takes a great deal of training. Composing doesn't work out easily but instead acquired through nonstop exertion and much practice. Moreover, students should assume the liability for their learning if significant learning is to occur.

The research questions are: 1) How are the students' writing ability in narrative text at the eighth grade of SMP Negeri 1 Gunungsitoli Barat in 2020/2021? 2)What are the factors that affect the students' writing ability in narrative text at the eighth grade of SMP Negeri 1 Gunungsitoli Barat in 2020/2021?

\section{RESEARCH METHOD}

In conducting the study, the researcher used the Descriptive Loeb et al (2017: 1) Qualitative Research by applying steps: documentation, interview. According to Gall,Gall, \& Borg, 2007 in Nassaji (2015: 129), The goal of descriptive research is to describe a phenomenon and it's characteristics. Tracy (2020: 6) says, "Qualitative data can be systematically gathered, organized, interpreted, analyzed, and communicated so as to address pressing concerns and prompt change". Then, to analyze the source of data, the researcher did it in two steps.

The quantitative data was analyzed to know the students' writing ability in narrative text. The data sources from the students' documentary worksheet. To conducted the data collection and analysis, the researcher used analytic scoring rubric by Glenceo (2009:17). Analytic scoring rubric has a few classifications. This class can be found in the accompanying table.

Table 1. Narrative Writing Analytic Scoring Rubric

\begin{tabular}{|c|c|c|c|}
\hline Aspects of Assessment & & iteria of assessm & \\
\hline Focus/Organization & $9-12$ & $5-8$ & $0-4$ \\
\hline $\begin{array}{l}\text { - The narrative satisfies its } \\
\text { motivation by recounting an } \\
\text { intriguing story. }\end{array}$ & $\begin{array}{l}\text { Interesting story } \\
\text { (generic) }\end{array}$ & $\begin{array}{l}\text { The story is } \\
\text { fascinating yet } \\
\text { may need } \\
\text { detail. }\end{array}$ & $\begin{array}{l}\text { Not intriguing } \\
\text { story and } \\
\text { indistinct or not } \\
\text { identified with } \\
\text { the point }\end{array}$ \\
\hline $\begin{array}{l}\text { - Time order is utilized to sort out } \\
\text { the story's occasions. }\end{array}$ & $\begin{array}{l}\text { Use time to } \\
\text { organize the } \\
\text { story's event }\end{array}$ & $\begin{array}{l}\text { The narrative } \\
\text { shows the } \\
\text { events, but may } \\
\text { lack details. }\end{array}$ & Not used time \\
\hline & $9-11$ & $5-7$ & $0-4$ \\
\hline
\end{tabular}


- The story is suitable to its target group.
The story is appropriate to audience

\author{
The story is for Not appropriate \\ some persons. \\ to audience
}

Score: 35

\begin{tabular}{l}
\hline Elaboration/Support/Style \\
\hline - $\begin{array}{l}\text { Every sentence is important to } \\
\text { the story. }\end{array}$ \\
- Transition words help move the \\
story along.
\end{tabular}

- Enough details are provided to describe the setting and characters.

9-12

5-8

5-8

0-4

Every sentences are strong and expressive with

riting is clea

Writing is varied structure. sentence may lack confusing, hard

Transitions are variety .

mature and

Transitions are present.

Transition are graceful

5-7

Setting and Characters are not detail.

Score: 35

\begin{tabular}{|c|c|c|c|}
\hline Grammar and Mechanics & $8-10$ & $5-7$ & $0-4$ \\
\hline $\begin{array}{l}\text { - The writing is free of } \\
\text { misspelling. }\end{array}$ & $\begin{array}{l}\text { Spellings are } \\
\text { generally correct. }\end{array}$ & $\begin{array}{l}\text { A few errors in } \\
\text { spelling }\end{array}$ & $\begin{array}{l}\text { Distracting errors } \\
\text { in spelling }\end{array}$ \\
\hline $\begin{array}{l}\text { - Sentences are punctuated } \\
\text { correctly. The words are } \\
\text { capitalized correctly. }\end{array}$ & $\begin{array}{l}\text { Punctuation and } \\
\text { capitalization } \\
\text { generally correct. }\end{array}$ & $\begin{array}{l}\text { A few errors in } \\
\text { punctuation } \\
\text { and } \\
\text { capitalization. }\end{array}$ & $\begin{array}{l}\text { Distracting errors } \\
\text { in punctuation } \\
\text { and } \\
\text { capitalization. }\end{array}$ \\
\hline $\begin{array}{l}\text { - A narrative text usually uses } \\
\text { past tense. }\end{array}$ & $\begin{array}{l}\text { Used past tense } \\
\text { correctly }\end{array}$ & $\begin{array}{l}\text { A few errors in } \\
\text { tenses }\end{array}$ & Errors in tenses \\
\hline \multicolumn{4}{|l|}{ Score: 30} \\
\hline
\end{tabular}

To determining the students writing ability, the researcher categorized the students' scores into four categories adapted from Purwanto in Sulityo (2013) it can be seen in the table below:

Table 2. Students Ability Category in Writing Narrative Text

\begin{tabular}{ll}
\hline Score range & Category \\
\hline $80-100$ & Excellent \\
$65-79$ & Good \\
$56-64$ & Fair \\
$<55$ & Poor \\
\hline
\end{tabular}

Analyzing the Qualitative Data (Cresswell:2014): Factors that Affect Students' Ability in Reading Comprehension

1. Reading and Make a Memo

The step centers around getting comfortable with the information and distinguishing likely subjects. The researcher read and write memos about observation sheets and the transcripts of interviews to get an initial sense of the data and identifying the themes. That's means, the 
researcher features some significant reply from the students that used to hear some data about their point of view in writing narrative text.

\section{Describing}

The progression centers around analyzing the information profoundly to give nitty gritty depictions of the setting, members, and action. In the progression, the specialist examines far reaching depictions of the members, the setting, and the wonder considered to pass on the rich intricacy of the examination. Thus, the point of this progression is to depict exceedingly significant things about the information like members' current circumstance, movement, etc.

\section{Classifying}

The step centers around classifying and coding bits of information and gathering them into topics. In the step, the researcher categorized all of the collected data into some classifications or categories. The researcher examines and compare all data, one to another to categorize them. For the interview data the researcher classified based on the order of student's interview, Gay, et al (2012:387) says, "In a formal structured interview, the researcher has a specified set of questions that elicit the same information from respondents".

Then, for the students' worksheet, the researcher classified the writing result based on the scoring rubric by Glenceo. The researcher will examine and compare all data, one to another to categorize them. Besides, Dörnyei (2007) say that Qualitative research involves data collection procedures that result primarily in open-ended, non-numerical data which is then analyzed primarily by statistical methods. Typical example survey research using a questionnaire, analyzed by statistical software such as SPPJ.

\section{RESULT AND DISCUSSION}

\section{Result}

Based on the data presented as well as the explanation of research findings. Fair to poor category were classified as a low score, excellent to good category were classified as a high score. In general, there were 7 students (35\%) included in 'Excellent' category, there were 4 students $(20 \%)$ included 'Good category, there were 3 students $(15 \%)$ included 'Fairy' category and category included in 'Poor' were 6 students $(30 \%)$. Through the result, the research classified 11 students as high and 9 students classified as low. Thus, the outcome demonstrated that the students' capacity in writing narrative text was high because from the students mean score obtained 66 score which was in an acceptable classification.

Furthermore, the aftereffect of the students' category on each aspect of writing showed that, in Focus/Organization aspect, there were $8(40 \%)$ students included in excellent category, there were $3(15 \%)$ students included in good category, there were $7(35 \%)$ students included in fair category and there were $2(10 \%)$ students included in poor. Through the result, there were 11 students as high and 9 students as low. It is indicated that the students had a good category in writing narrative text based on the focus/organization aspect.

The result of another aspect showed that, there were $5(25 \%)$ students included in excellent category, there were $6(30 \%)$ students included in good category, there were $8(40 \%)$ students included in fair category and there were $1(5 \%)$ students included in poor for the Elaboration/Support/Style aspect. Through the result, there were 11 students as high and 9 students as low. It is indicated that the students had a good category in writing narrative text based on the Elaboration/Support/Style aspect. 
Furthermore, the result of the Grammar and Mechanics aspect showed that, there were 3 $(15 \%)$ students included in excellent category, there were $9(45 \%)$ students included in good category, there were $7(35 \%)$ students included in fair category and there were $1(5 \%)$ students included in poor. Through the result, there were 12 students as high and 8 students as low. It is indicated that the students had a good category in writing narrative text based on the Grammar and Mechanics aspect.

\section{Discussion}

\section{Factor Affecting the Result of Focus/ Organization Aspect}

Based on the students' responses, there were some reasons that affecting the students' ability in Focus/Organization aspect. Some students who achieved excellent category stated that they understand the generic structure of the text. In another hand, some students who achieved the good category stated that they had little problem with expressing the idea. Another student say that they had little difficult in writing the complication. Furthermore, some students who achieved fair and poor category say that they faced problem about less understanding the structural text, another student say that they were less interesting to study the material and some of students say that it was difficult for them to write complication and resolution. Another reason was they were lack of practice in writing a text.

\section{Factor Affecting the Result of Elaboration/Support/Style Aspect}

Based on the students' responses, there were some reasons that affecting the students' ability in Elaboration/Support/Style aspect. Some students who achieved the excellent category said that they understand how to support their writing narrative text. In another hand, some students who achieved the good category stated that they have little problem with mastering vocabulary so they could not express their idea to write the narrative text. Furthermore, some students who achieved fair and poor category stated that they were did not understand how to support their writing and another say that they did not focus to study because less interest to study the material.

\section{Factors Affecting the Result of Grammar and Mechanics Aspect}

Based on the students' responses, there were some reasons that affecting the students' ability in Grammar and Mechanics aspect. Some students who achieved the excellent category said that they understand the grammar and mechanics in writing narrative text. In another hand, some students who achieved the good category stated that they had little problem with formula of simple past tense, little problem of vocabulary especially miss spelling word and punctuations. Furthermore, some students who achieved fair and poor category stated that it was difficult for the students to use the simple past tense, another student stated that they could not differentiated English form and Indonesia language form in writing narrative text and difficult to follow the material of narrative text especially in used simple past tense.

Based on the result of students' and teacher's interview, it very well may be finished up there were a few factors that affect the students' ability in writing narrative text namely: content and problem organization, lack of grammar, lack of practice, lack motivation and the impact of the primary language (L1) on writing in English. It is supported by Nile et al (2015) stated that there some problems that affect students writing ability: Cognitive Problem, Grammatical Problems and Lack of Practice. Furthermore, according to Nacira in Asiahet al (2020:88) stated that factors that hamper students to write were: lack of motivation and the influence of the first language (L1) on writing in English. 


\section{CONCLUSION}

Managing the consequence of the examination from the students' worksheet and interview, it could be concluded that the ability of students of class VIII-A at SMP Negeri 1 Gunungsitoli Barat in writing narrative text was in good category. It is proved by the findings that there were 7 students (35\%) included in 'Excellent' category, there were 4 students (20\%) included 'Good category, there were 3 students (15\%) included 'Fair' category and category included in 'Poor' were 6 students (30\%). Through the result, the research classified 11 students as high and 9 students classified as low. So, the result indicated that the students' ability in writing narrative text was high because from the students mean score obtained 66 score which was in good category.

The research findings also indicate that the major factors that affecting the students' ability in writing narrative text were: students cognitive it was problem organization, less motivation, lack of grammar, lack of practice and the influence of the first language (L1) on writing in English.

Based on the result of the research, there are some suggestion proposed by researcher namely: The English Teacher should pay attentions in engaging the students more in teaching learning activities. The English Teacher encourages their students to produce better writing by giving them much practice to write. In addition, the students should read more and practice to write more to increase their ability in writing especially narrative text and the students should learn more simple past tense, structure of narrative text, proponents of narrative text such as transition word, and do not hesitate to ask the teacher if they have difficulties on it. For the further researchers who want to analyze the students' writing ability in different aspects of the research and making the research as the reference in the same field to be able to cover the limitation about the research as well. Especially in determining the indicators used as research indicators in order to used more complete indicators so that students' writing assessments were better.

\section{REFERENCES}

Asiahet al, (2020). A Study on The Students' Factor Difficulty in Writing Narrative Text at VIII Grade of Mts Sabilal Muhtadin Tembilahan. Vol.1. No.2.

Creswell, J. W. (2014). Research design : Qualitative, Quantitaive, and Mixed-method Approach (4th ed.). California.

Dörnyei, Z. (2007). Research Methods in Applied Linguistics. Oxford: University Press.

Gay, L. R., Mills, G. E., Airasian, P. W. (2012). EDUCATIONAL RESEARCH: Competencies for Analysis and Aplications (10th Ed.). New York: Pearson.

Glenceo. (2009). Writing Assessment and Evaluation Rubric. California: MCGrew Hill.

Hosien. N. (2015). Qualitative and descriptive research: Data type versus data analysis. SAGE, Volume 19(2), Number 129-132.

Loeb, et. al. (2017). Descriptive Ananlysis in Education: a Guide for Researchers. (NCEE) National Center for Education Evaluation. 
The Descriptive Analysis of Students' Writing Ability in Narrative Text at the Eighth Grade of SMP Negeri 1 Gunungsitoli Barat in 2020/2021

Hasrat Sozanolo Harefa, Joshua Obedience Zebua IKIP Gunungsitoli

Lubis, R. F. (2016). Narrative Text. English Education. Vol 4. No 2.

Mustika, G., et al. (2018).Students' Writing Process for Project Ibunka: ACase Study of EFL Writers. JELTL (Journal of English Language Teaching and Linguistics) 3(3).

Noviani, T. (2015). Students' Problems in Writing Generic Structure of Narrative Text at Second Grade SMAN 1 Sungai Rumbai Dharmasraya.

Rani, A. and Melati, T. (2018). Improving Students' Writing Skill of Recount Text Through Diary Writing Peer Editing Technique. ICOELT-6.

Sarah, J. T. (2020). Qualitative Research Methods: Collecting Edvidaence, Crafting Analysis, Communicating Impact. Wiley Blackwell. 